\title{
EMBODIED GREENHOUSE GAS EMISSIONS FOR TWO DIFFERENT TYPES OF TIRE TREAD MOLDS
}

\author{
Pawinee Suksuntornsiri ${ }^{1}$, Monsit Kulamart ${ }^{2}$, and Paiboon Limpitipanich ${ }^{\mathbf{1}}$ \\ ${ }^{1}$ Mechanical Engineering Department, ${ }^{2}$ Master of Engineering in Energy and Environment Management, Faculty \\ of Engineering, Burapha University, Chonburi, Thailand, Tel: +6638102222, e-mail: pawinee@eng.buu.ac.th
}

Received Date: March 4, 2019; Revised Date: September 22, 2019; Acceptance Date: November 29, 2019

\begin{abstract}
In an assessment of the carbon footprint (CFP) of a tire product, embodied greenhouse gas (GHG) emissions of its tread mold are usually disregarded due to the absence of available information. This study presents embodied GHG emissions of a winter tire tread mold and evaluates its significance. We also provide a comparative study between two types of mold, namely the sector and the element mold, which are not different in terms of the tread forming in the production process, but subject to the customer's utilization. The assessment was performed according to the international ISO/DIS 14067 standard, requirements, and guidelines for the quantification of the CFP of products. Required input data of the processes were collected and allocated based on a tread mold production plant located in Thailand. Direct GHG emissions and indirect emissions were calculated according to the 2006 IPCC guidelines. In other indirect processes, secondary data from process-based and input-output-based data were assigned to match the best site specificity, and closer fuel mix in upstream inputs. The results obtained in this study show that the embodied GHG emissions were 5,033.36 $\mathrm{kg} \mathrm{CO}_{2 \mathrm{e}}$ for the sector mold, whereas $53.73 \%$ additional emissions were found in the dataset using the element mold. The embodied emissions estimated for the aluminum input were found to significantly influence the mold CFP. Disregarding the embodied GHG emissions during the production of a single conventional tire could result in an underestimation of $0.03 \%$ for the sector type and $0.05 \%$ for the element type. Furthermore, appropriate lifetime utilization of the tread mold could increase the contribution of the tread mold CFP.
\end{abstract}

Keywords: Carbon footprint, CFP, GHG, LCA, Tire, Tread mold

\section{Introduction}

The carbon footprint (CFP) of a product represents the summation of greenhouse gas (GHG) emissions, i.e., embodied greenhouse gas emissions produced during that product's lifecycle. To evaluate the CFP, direct emissions from the main process, along with emissions from upstream and downstream processes are taken into account via a standard life cycle analysis (LCA) approach. LCA emissions in the final consumer's point of view are influential to the consumer's choice regarding mitigations.

A comparison between two exchangeable energy systems should be assessed within the same boundary scope, comparable lifetime, and reflect the real embodied energy and economic activities from the origin of upstream materials and services $[1,2]$. However, in a process analysis, an identical boundary scope is never met because of different systems, data availability, and researchers' justification [3].

Two approaches are available for the LCA, i.e., the process analysis (PCA) and inputoutput analysis (IOA). The PCA performs better with regard to the representation of the identified process, as it is derived from the primary data collection [4]. However, not all of the 
data in the higher level of upstream links can be reached, and the related service links cannot be measured [5]. Occasionally, these data are disregarded. In cases where the data from the country of origin of the upstream processes are unavailable, they are sometimes obtained from other countries. The PCA also involves long-term tasks, and some upstream energy contents are outdated by the time they are completed $[6,7]$.

The IOA is an energy-economic model that is valuable in a wide range of applications in energy economy and environmental studies $[8,9]$. The major advantage of IOA is that it can enlarge the LCA boundary scope to infinite subprocesses and embodied energy, and GHG emissions in service processes could be taken into account. Its drawback is that its sectoraverage value is assumed to represent real activity [10], and any sector misallocation could result in multiple overestimations.

A proper approach would involve a combination of PCA and IOA, i.e., hybrid PCAIOA, which could overcome both drawbacks of the IOA or PCA [1, 5]. In the hybrid method, the embodied emissions from the PCA should be obtained by primary data collection in the main process. In upstream subprocesses, embodied GHG emissions, or the so-called CFP, must be available in relevant physical units. In other process links, where the PCA-based CFP is not available, the embodied GHG emissions factors in monetary terms, namely the IOA-based CFP, can be used for estimating individual input with monetary units. The embodied energy and GHG of input materials have to be recorded for a country data set for LCA purposes, either by collecting abundant data via PCA or applying sectoral average data specified by IOA methods [11].

The selection of a site-specific emission factor influences the CFP result $[1,12]$. A study by Tadtiemporn [13] presented a large deviation of a sticky-rice product's CFP using two different site factors of local rice, i.e., the local factor and one from a European country. A study by Itsubo, Inaba, and Matsumoto [14] on the development of the inter-regional IO-based LCA method considering region-specific indirect effects, and another study by Cicas et. al. [15] on a regional version of US IOA-LCA model motivated the attempt to reduce the LCA site-specific problem by integration of indirect effects of upstream processes using inventory data from the local IOA.

Some applications of the derivation of embodied energy and emissions of products by IOA were found in the works by Bullard and Herendeen [16], Chapman [17], and Suksuntornsiri and Limmeechokchai [6]. An application of the energy and emissions for LCA in Japan was provided in a report by the National Institute for Environmental Studies [10]. Other IOA for LCA applications for the comparative assessment of different power generating technologies were presented by IAEA [18].

Since the input-output table consists of historical data, whose tabulation would require several years, the IOA would better represent the activity when the energy consumption pattern related to its economic structure is constant. Some structural adjustments on the existing inputoutput table could improve the IOA to some extent. The fuel mix in the power sector that significantly influences energy and GHG intensities in material and services was updated from previous studies [7] and applied in the IOA of this study.

The continuously increasing needs of transportation fuel the growth of the world's demand for new vehicles. The International Organization of Motor Vehicle Manufacturers reported that the world's vehicle production in 2017 amounted to 97.3 million units, which indicated an increase from 2016 by $2.36 \%$ [19]. From the marketing point of view, development 
and innovation for a better performance of tires is required for brand new cars. The tire tread pattern is a significant factor in enhancing driving performance and safety. Along with the continuing research development in tire technology, a newer tread pattern is frequently implemented, which induces demand of the tread mold replacements.

The tire manufacturing process starts with mixing a compound of rubber and additives, which are then assembled with an inter-liner, body piles, belts, and steel wire. The final step is to insert them inside the tire mold and inflate them to press against the sidewall of the mold, forming the tire tread [20]. A set of tire molds is comprised of two major components, namely a steel mold and an aluminum mold. The tire tread mold is made of aluminum, and it plays an important role in the forming of the tread pattern. The tread mold is currently produced by two available methods, namely multi-axis CNC machining and precision casting [20]. The latter is commonly used.

The two exchangeable tread mold types are the sector and element types. Each piece of the sector type is observed to be larger than the element type pieces. There could be 8 to 12 pieces of sector mold or 60 to 80 pieces of element mold within a set of tread molds. The cost of a set of the sector-type mold is less; however, replacing each piece is expensive. A highproduction company prefers the element type because of the high usage of mold for tire production. However, due to the decreased usage of mold for tire production and the decreased wear probability in a low-production company, the sector type is selected.

The tread mold is considered as one of capital inputs of the tire forming process. It is embodied GHG emissions do exist, however they are usually unknown and disregarded. In an example of a study of the CFP of an airless one-piece wheel-and-tire with a rubber tread bonded to a wheel hub assessed by Bras and Cobert [21], $544.8 \mathrm{~kg} \mathrm{CO}_{2}$ was produced for the new tire model, while $560.4 \mathrm{~kg} \mathrm{CO}_{2 \mathrm{e}}$ was produced in the conventional tire. However, capital inputs were not taken into account.

This study provides a hybrid PCA-IOA assessment on embodied GHG emissions in a winter tire tread mold produced in Thailand, to evaluate its value as a capital input in the tire production process. Moreover, to provide a global warming option for a tread mold selection, a comparison of the CFP of two different tread molds, i.e., the sector and the element type, for the winter tire are also presented. Furthermore, this study discovers variations in the tread molds' obtained CFP derived from CFP data using different required input.

\section{Methodology}

To provide an assessment of embodied GHG emissions in a set of tire tread molds, the international guidelines for CFP, ISO14067 [22], were applied. These provide detailed principles, requirements, and guidelines for the quantification and communication of the CFPs of a product, based on GHG emissions and removals during its life cycle. The CFP guideline complies with the ISO 14044:2006 [23], a standard procedure for LCA. In this study, the life cycle inventory procedure was applied to provide energy and GHG emissions subject to the defined functional unit (FU).

\section{Aim and Scope}

The aim of this study is to provide an assessment of the CFP of a set of tire tread molds. A set of tire tread molds is defined as the FU. A comparative assessment on two available tread molds, the sector and the element type, which are exchangeable in the production of a winter tire, was performed. 


\section{Process Analysis}

The process analysis of production of a typical tire tread mold is shown in Figure 1. Within the main process boundary (depicted by the dashed line box), process flows performed similarly in each machine, both for sector mold or element mold production, whereas they differ in the input requirements and production time of each machine. The main process begins with the mold design process, followed by master model milling, plate cutting, silicone casting, plaster casting, aluminum casting, aluminum milling, packing, and transportation to the shipping area.

The input flows in the main process start from the supply of variable inputs in the horizontal flow. Capital inputs, i.e., machine, capital materials, and component flow (in the vertical flow) are also taken into account. Scraps were disregarded due to unavailable co-product allocation data.

Direct and embodied emissions were assessed considering variable inputs in horizontal flows and capital inputs in vertical flows. The source of inputs influences the embodied energy mix and GHG emissions. Figure 1 lists the countries of origin of individual variable inputs. The origins of capital inputs were not recorded, and they are therefore assumed to be supplied by local industry.

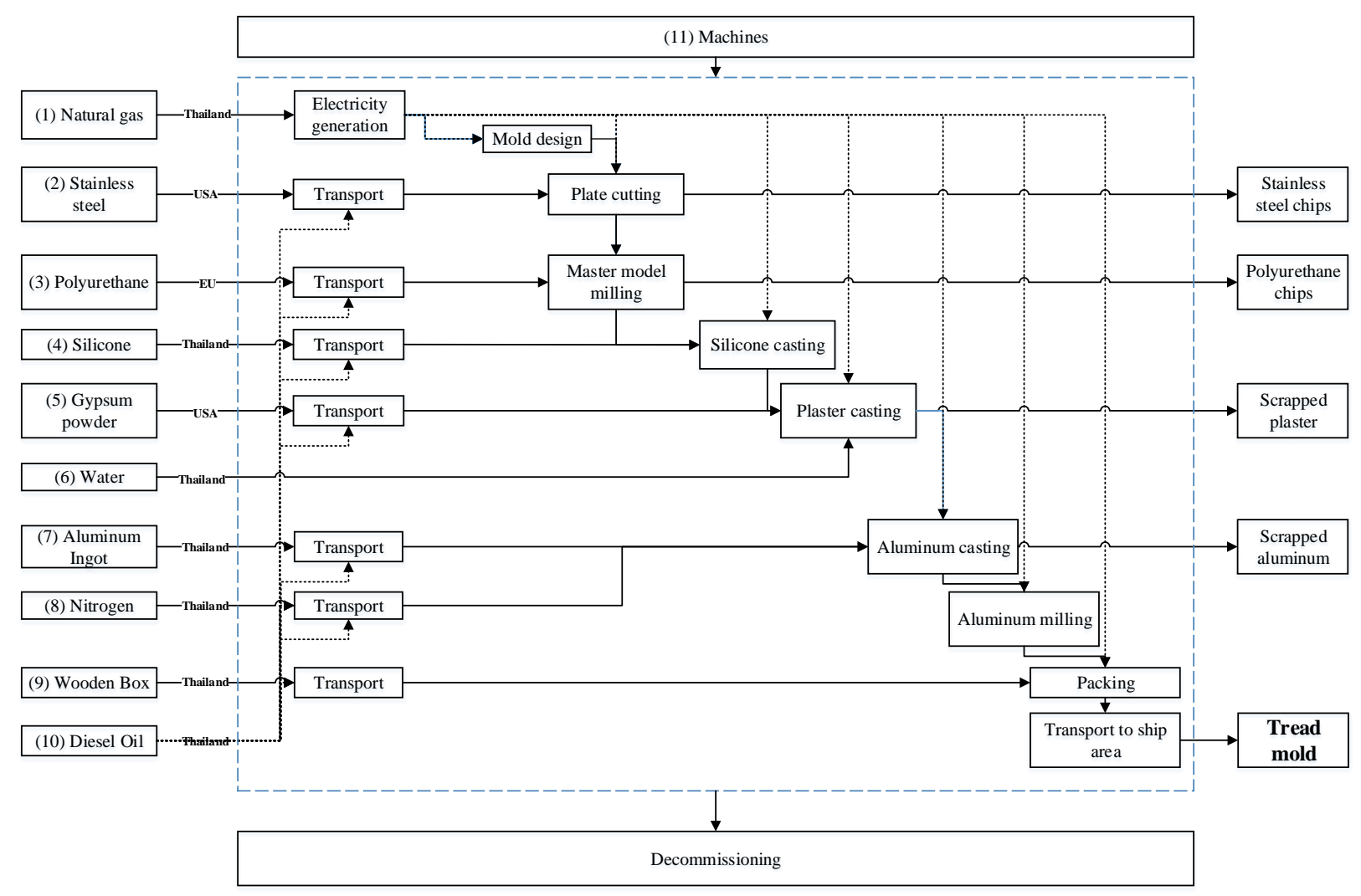

Figure 1. Process analysis of typical tire tread mold

\section{Inventory Analysis and Calculations}

Based on the resource allocation inside the boundary, the inventory of a tire tread mold production process was analyzed in horizontal and vertical flows of the processes defined in Figure 1. The variable inputs required per one unit of tread mold were collected from the three years of data recorded. 
In the calculations, the product CFP, i.e., lifecycle-GHG emissions are comprised of two main contributions, namely direct and indirect emissions:

$$
C F P=\sum_{k=1}^{p} \text { direct } G H G \text { emissions }_{k}+\sum_{j=1}^{m} \text { indirect } G H G \text { emissions }_{j},
$$

in units of $\mathrm{kg} \mathrm{CO}_{2 \mathrm{e}} / \mathrm{FU}$, where direct $\mathrm{GHG}$ emission $_{k}$ depicts direct $\mathrm{GHG}$ emissions from fossil fuel combustion during activity $\mathrm{k}$ within the main process generated to produce one set of molds ( $\left.\mathrm{kg} \mathrm{CO}_{2 \mathrm{e}} / \mathrm{FU}\right)$; indirect GHG emission $_{j}$ depicts embodied GHG emissions in each required input $\mathrm{j}$ per one set of molds $\left(\mathrm{kg} \mathrm{CO}_{2} \mathrm{e} / \mathrm{FU}\right)$.

GHG emissions were assessed based on IPCC guidelines [24]:

$$
\text { direct emission }=\text { fuel consumption } \times I P C C \text { emission factor, }
$$

in units $\mathrm{kg} \mathrm{CO}$ e/one set of mold, and

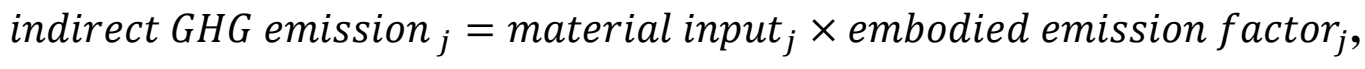

where material input $_{j}$ is the amount of variable or capital input per FU in monetary or physical units, depending on the type of embodied emission factor, embodied emission factor $_{j}$ that depicts the life cycle $\mathrm{GHG}$ emissions of $\mathrm{j}$ product in $\mathrm{kg} \mathrm{CO}_{2} \mathrm{e} /$ monetary unit or $\mathrm{kg} \mathrm{CO}_{2}$ /physical unit.

The contribution of total GHG emissions, or CFP, in energy inputs is comprised of two components: direct emissions that can be assessed by Equation (2) and embodied emission that can be assessed by Equation (3).

The embodied emission factor given by Equation (3) can be found from the life cycle GHG emissions of products either from the PCA data $\left(\mathrm{kg} \mathrm{CO}_{2} \mathrm{e} /\right.$ physical unit) or IOA data $(\mathrm{kg}$ $\mathrm{CO}_{2 \mathrm{e}}$ /monetary unit). The amount of material input for calculation with the PCA must be in corresponding physical units, and for the IOA it must be in monetary units.

Since the selection among different sources of embodied emission factors significantly depend on the actual source of inputs, they must be assessed from the corresponding country.

PCA was applied within the main process and enhanced using embodied emission factors derived from relevant CFP literature. Local factors of some upstream links, where PCA was unavailable, were assessed using emission factors from local IOA data in Ref. [25].

\section{Direct and Embodied Emissions in Transportation}

In this study, there are two types of energy inputs that flow into the main system, namely diesel fuel consumed in raw material transportation and natural gas electricity consumed by process machines. The first portion of direct emissions in the main process is due to diesel consumption in the transportation of raw materials. Fuel economy, load, and distance for the transportation of polyurethane, stainless steel, silicone, gypsum powder, aluminum ingot, nitrogen, and wooden box were summed for each load delivery per trip.

In the transportation of supplied inputs, fuel consumption was calculated as follows:

$$
\text { fuel consumption }=\sum_{i=1}^{n} \frac{\text { input required per mold } \text { m }_{i} \times \text { transport distance }_{i}}{\text { load transport per trip }{ }_{i} \times \text { fuel economy }_{i}}
$$


where input required per mold is $_{i}$ the portion of input $i$ required for a set of tread mold production; transport distance ${ }_{i}$ depicts a round trip distance covered to deliver the input $\mathrm{i}$ from port or supplier; load transport per trip $_{i}$ is the capacity of input $\mathrm{i}$ that is delivered by the truck, and fuel economy $y_{i}$ is the average distance traveled per fuel consumed by the $\mathrm{i}$ material in the transport truck $(\mathrm{km} / \mathrm{L})$.

The fuel consumption per one mold was estimated based on a fuel economy of 5.14 $\mathrm{km} / \mathrm{L}$, assumed from primary data collection. Table 1 presents fuel consumed for the delivery of each input material to the production plant, assessed from Equation (4) and direct $\mathrm{CO}_{2}$ emissions assessed by Equation (2). A total of 1.151 L diesel fuel is required for the transportation of raw material used to produce one set of sector molds. In turn, the production of a set of element molds requires 2.360 L of diesel fuel. Direct GHG emissions resulting from the material transportation for the sector mold amounted to $3.061 \mathrm{~kg} \mathrm{CO}_{2 \mathrm{e}}$, and $6.277 \mathrm{~kg} \mathrm{CO}_{2 \mathrm{e}}$ for the element mold.

Since this amount of diesel consumption was delivered from the local refinery sector, indirect GHG emissions in the upstream process were further assessed by Equation (3) based on the IOA of an economic sector 093 petroleum refinery \& gas separation plant (28.5 ton $\mathrm{CO}_{2}$ /million baht). Embodied $\mathrm{CO}_{2}$ emissions in the upstream process of this supplied diesel oil amounted to $0.830 \mathrm{~kg}$ in the sector mold and $1.703 \mathrm{~kg}$ in the element mold. Results show that the transportation of nitrogen and the wooden box contributed the largest share due to the transportation distance and smaller load per trip.

LPG consumption in the process of transportation of the finished product to the shipping area was disregarded due to short traveling distance and unavailable data.

Table 1. Fuel Consumption and Direct $\mathrm{CO}_{2}$ Emissions in Transportation

\begin{tabular}{|c|c|c|c|c|c|c|}
\hline \multirow[t]{2}{*}{$\mathbf{F}$} & \multirow[t]{2}{*}{ Raw Materials } & \multirow{2}{*}{$\begin{array}{c}\text { Transport } \\
\text { Distance } \\
\text { (km) }\end{array}$} & \multicolumn{2}{|c|}{$\begin{array}{l}\text { Diesel Consumption in } \\
\text { Transportation }(\mathrm{L})\end{array}$} & \multicolumn{2}{|c|}{$\begin{array}{c}\text { Direct } \mathrm{CO}_{2} \text { Emission } \\
(\mathrm{kg})\end{array}$} \\
\hline & & & Sector & Element & Sector & Element \\
\hline (2) & Stainless steel & 4.7 & 0.009 & 0.009 & 0.025 & 0.025 \\
\hline (3) & Polyurethane & 4.7 & 0.000 & 0.000 & 0.001 & 0.001 \\
\hline (4) & Silicone & 4.7 & 0.000 & 0.001 & 0.001 & 0.002 \\
\hline (5) & Gypsum powder & 4.7 & 0.002 & 0.014 & 0.005 & 0.037 \\
\hline (7) & Aluminum ingot & 81.8 & 0.088 & 0.451 & 0.234 & 1.200 \\
\hline (8) & Nitrogen & 97.8 & 0.638 & 1.472 & 1.697 & 3.916 \\
\hline (9) & Wooden box & 106 & 0.412 & 0.412 & 1.097 & 1.097 \\
\hline \multirow{2}{*}{\multicolumn{3}{|c|}{$\begin{array}{l}\text { Direct Energy/Emissions } \\
\text { Indirect Emissions }\end{array}$}} & 1.151 & 2.360 & 3.061 & 6.277 \\
\hline & & & & & 0.830 & 1.703 \\
\hline
\end{tabular}

\section{Direct and Embodied Emissions in Electricity Consumption}

First, the CFP of natural gas electricity was derived to be used as an embodied emission factor in electricity in Equation (3) for derivation of indirect GHG emissions from electricity consumption by process machines.

The electricity consumed by this production plant was purchased from a private power plant and generated from a natural gas pipeline. Because specific process data was not available, the electricity generation from the natural gas power plant that belonged to the national grid [26] was assumed as electricity supplied from the local private power plant in this study. 
Figure 2 illustrates the scope of direct and indirect GHG emissions considered in the electricity CFP in this study. Inclusion is depicted by solid line box, while the exclusion of some other upstream inputs are depicted in dashed line box. Table 2 shows the calculation of natural gas electricity from the Thai grid in 2017, which was applied as embodied GHG emission in the process electicity in the same year. The portion of direct GHG, estimated by Equation (2), amounted to $0.6283 \mathrm{~kg} \mathrm{CO} / \mathrm{kWh}$. Indirect GHG emissions, estimated by Equation (3) with the Thai-IOA emission factor [25] in the pipeline sector, yielded embodied GHG emissions upstream of natural gas supplied to electricity generation of $0.315 \mathrm{~kg} \mathrm{CO}_{2} / \mathrm{kWh}$. Because of the unavailability of upstream process data of other inputs, these were disregarded. Finally, the total CFP of electricity estimated by Equation (1), was calculated to be $0.944 \mathrm{~kg} / \mathrm{kWh}$.

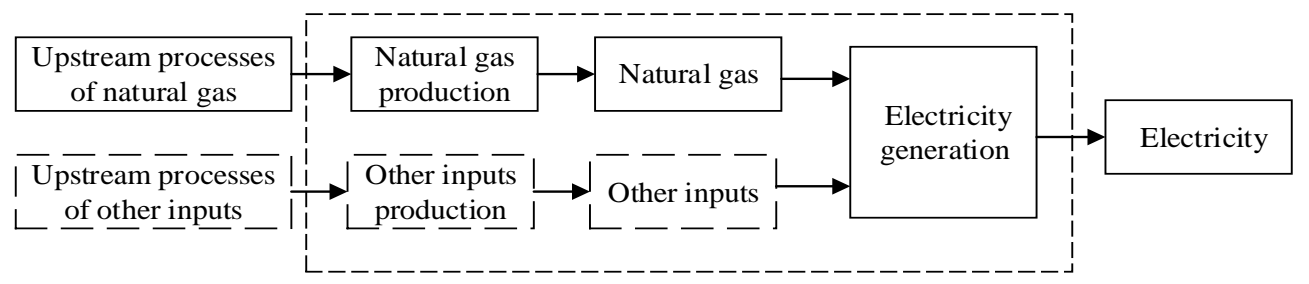

Figure 2. Upstream process and assessment of electricity CFP

Table 2. Assessment of Natural Gas Electricity CFP

\begin{tabular}{|c|c|c|}
\hline Item & Amount & Unit \\
\hline Thai electricity generation from natural gas [26] & $39,939.96$ & GWh \\
\hline Natural gas consumption for power generation [26] & 423,940 & mmscf \\
\hline IPCC emission factor [24] & 56,100 & $\mathrm{~kg} / \mathrm{TJ}$ \\
\hline $\mathrm{CO}_{2}$ emissions from natural gas electricity & $25,092,432,720$ & $\mathrm{~kg} \mathrm{CO} 2 \mathrm{e}$ \\
\hline Embodied GHG emissions in natural gas supplied [25] & 110.01 & $\begin{array}{c}\text { ton } \mathrm{CO}_{2 \mathrm{e}} / \text { million } \\
\text { baht }\end{array}$ \\
\hline Natural gas price & 270 & baht/mmbtu \\
\hline Direct emission factor from natural gas electricity & 0.6283 & $\mathrm{~kg} / \mathrm{kWh}$ \\
\hline $\begin{array}{l}\text { Embodied emissions in upstream natural gas supplied } \\
\text { Thai-IOA derived }\end{array}$ & 0.3153 & $\mathrm{~kg} / \mathrm{kWh}$ \\
\hline $\begin{array}{l}\text { Total embodied GHG emissions in natural gas } \\
\text { electricity }\end{array}$ & 0.944 & $\mathrm{~kg} \mathrm{CO}_{2 \mathrm{e}} / \mathrm{kWh}$ \\
\hline
\end{tabular}

Each machine's required electricity consumption, i.e., the computer, milling machine, laser cutting machine, mixing machine, and low pressure casting machine was assessed based on its power and operating time required for each unit. The total electricity consumption in the sector and element mold were 2,880.59 $\mathrm{kWh}$ and 3,565.78 $\mathrm{kWh}$, respectively. Table 3 presents the electricity consumption and GHG emissions effectuated by process machines.

According to the natural gas electricity $\mathrm{CFP}$, total $\mathrm{CO}_{2}$ emissions by consumption of electricity for the sector and the element mold were $2,717.926 \mathrm{~kg} \mathrm{CO}_{2 \mathrm{e}}$ and 3,364.426 $\mathrm{kg} \mathrm{CO}_{2 \mathrm{e}}$, respectively. In the electricity consumption of individual machines, although the element mold had the advantage of lower electricity demand in the master mold process, the higher demand in the aluminum casting and milling generates higher net embodied emissions in the electricity used for the element mold. 
Table 3. Electricity Consumption and GHG Emissions by Machines

\begin{tabular}{|c|c|c|c|c|}
\hline \multirow[t]{2}{*}{ Process Machine } & \multicolumn{2}{|c|}{$\begin{array}{c}\text { Electricity Consumption } \\
(\mathbf{k W h})\end{array}$} & \multicolumn{2}{|c|}{$\begin{array}{c}\text { GHG Emissions } \\
(\mathrm{kg} \mathrm{CO} 2 \mathrm{e})\end{array}$} \\
\hline & Sector Mold & Element Mold & Sector Mold & Element Mold \\
\hline Computer & 18.00 & 18.00 & 16.984 & 16.984 \\
\hline Laser cutting machine & 0.88 & 0.88 & 0.830 & 0.830 \\
\hline Master milling machine & $2,280.00$ & $1,125.00$ & $2,151.251$ & $1,061.473$ \\
\hline Silicone mixing machine & 30.94 & 10.47 & 29.193 & 9.874 \\
\hline Plaster mixing machine & 36.00 & 72.00 & 33.967 & 67.934 \\
\hline $\begin{array}{l}\text { Low pressure casting } \\
\text { machine }\end{array}$ & 410.52 & $1,519.69$ & 387.338 & $1,433.872$ \\
\hline $\begin{array}{l}\text { Aluminum milling } \\
\text { Machine }\end{array}$ & 104.25 & 819.75 & 98.363 & 773.460 \\
\hline Total & $2,880.59$ & $3,565.78$ & 2,717.926 & $3,364.426$ \\
\hline
\end{tabular}

\section{Embodied GHG Emissions in Raw Materials and Capital Inputs}

Indirect and embodied emissions, generated in the upstream processes of variable inputs in horizontal flows, as well as capital inputs in vertical flows (as shown in Figure 1) were assessed by Equation (3). In the case where process-based emission data, i.e., life cycle GHG emissions of the input in terms of emissions per physical unit, were available, the amount of variable inputs was assessed based on the volume, density, or mass of materials in primary data. In the other case, the cost share in monetary units per FU was applied to obtain an evaluation of life cycle GHG emissions per monetary unit, i.e., IOA-based data, in Equation (3).

Table 4. Selected 2017 Thai-IOA Emission factors [25] （unit: ton $\mathrm{CO}_{2 \mathrm{e}} /$ million baht)

Input Economic Sector

\begin{tabular}{llc}
\hline (1) Natural gas & 136 Pipeline and gas distribution & 110.01 \\
(4) Silicone & 86 Petrochemical products & 70.32 \\
(6) Water & 137 Water supply system & 25.09 \\
(7) Aluminum ingot & 107 Nonferrous metal & 74.74 \\
(8) Nitrogen & 84 Basic chemicals & 134.14 \\
(9)Wooden box & 79 Wood and cork products & 19.21 \\
(10) Diesel oil & 93 Petroleum refineries \& gas separation plant & 28.49 \\
(11) Process machines & 114 Wood and metal working machines & 35.27 \\
\hline
\end{tabular}

Considering a calculation of indirect emissions from input-output based data in Thailand, it was found that the Thailand IO table [27] requires about four years to be reported, and it is usually reported at an interval of every four to five years. Recent energy and GHG intensities were assessed by Ref. [25], and they was derived from the 2010 IO table from 180 sectors [27] and the 1998 sectoral energy consumption. The 2017 energy and GHG intensities factors were further derived by updating the annual fuel mix of the power sector [7], which is influential to all other commodities in the economy. The electricity fuel mix, efficiencies, electricity price, transmission and distribution losses, and own use in the power sector were taken into account. The factors in the production related year, 2017 were selected. 
The inventory analysis of inputs has been described, considering the correct proportions corresponding to the process presented in Figure 1. Indirect emissions from the upstream process of available and best-fitting embodied emission factors provided in Table 5 were used to calculate the indirect GHG emissions by substituting the physical inputs data into Equation (3).

Table 5. Emission Factors of Variable Inputs from References

\begin{tabular}{lccl}
\multicolumn{1}{c}{ Table 5. Emission Factors of Variable Inputs from References } & (Unit: $\mathrm{kg} \mathrm{CO}_{2 \mathrm{e}} / \mathrm{kg}$ ) \\
\hline & $\begin{array}{c}\text { Supplier } \\
\text { Site }\end{array}$ & $\begin{array}{c}\text { Embodied } \\
\text { Emission factor } \\
\text { (EF) }\end{array}$ & \multicolumn{1}{c}{ Reference } \\
\hline (2) Stainless Steel & USA & 5.019 & $\begin{array}{l}\text { Suksuntornsiri et.al. [25] } \\
\text { Hammon and Jonnes [28] }\end{array}$ \\
\hline (3) Polyurethane & EU & 4.200 & Ruuska [29] \\
\hline (5) Gypsum Powder & USA & 0.12 & Hammon and Jonnes [28] \\
& & 0.2432 & Ruuska [29] \\
\hline (7) Aluminum Ingot & Thai & 6.097 & Suksuntornsiri et.al. [25] \\
& & $2.264-23.96$ & [28] [29] [30] [31] [32] \\
\hline
\end{tabular}

The process-based embodied emissions factors of stainless steel, polyurethane, and gypsum powder were selected to be assessed by PCA. First, the amount of required stainless steel either by the sector or the element mold was not different. Using embodied emissions values from Hammon and Jonnes [28], $6.15 \mathrm{~kg} \mathrm{CO}_{2} / \mathrm{kg}$ was applied in this assessment. However, with the local IOA emission factor (61.52 tonCO $\mathrm{Ce}_{2} /$ million baht [25] or $5.019 \mathrm{~kg} \mathrm{CO} 2 \mathrm{e} / \mathrm{kg}$ ), this value was slightly underestimated.

Second, since polyurethane imported from EU was used in the process, embodiedGHG emissions $(4.200 \mathrm{~kg} \mathrm{CO} 2 \mathrm{e} / \mathrm{kg})$ of European polyurethane from the study of Ruuska [31] was applied in this study.

Third, the gypsum plaster powder imported from USA was used in the process. From the ELCD database 2.0, 0.2432 $\mathrm{kg} \mathrm{CO}_{2 \mathrm{e}} / \mathrm{kg}$ from the data set by PE International in Ruuska [31] was applied in this study. Another available value obtained by Hammon and Jonnes [28], which was significantly lower $\left(0.12 \mathrm{~kg} \mathrm{CO}_{2 \mathrm{e}} / \mathrm{kg}\right)$, was not chosen.

Finally, the tread mold is made of aluminum (input no. 7), which contributes significantly to the mold's CFP. Although it was obtained from Thai suppliers, site-specific, process-based data could not be found. The use of local IOA data must be accepted, under the assumption that it is an average emission factor from the sector. Moreover, since upstream aluminum industries are hardly present in Thailand, this embodied emission may be underestimated. Large variations in the aluminum emission factor were found in other countries. An assessment of Das and Kandpal [30] on $\mathrm{CO}_{2}$ emissions from aluminum produced from four factories located in Balco, Hindalco, Indal, and Nalco in India estimated $21.370 \mathrm{~kg} \mathrm{CO} 2 \mathrm{e} / \mathrm{kg}$, and $19.570 \mathrm{~kg} \mathrm{CO} 2 \mathrm{e} / \mathrm{kg}$ after energy efficiency improvement. In China, a model study by Zhang et al. [31] presented $13.190 \mathrm{~kg} \mathrm{CO} / / \mathrm{kg}$ emission factor of aluminum ore and $10.990 \mathrm{~kg} \mathrm{CO} 2 \mathrm{e} / \mathrm{kg}$ of aluminum in mining. In contrast, lower emissions were found in European countries. Hammon and Jonnes [28] provided data of $\mathrm{CO}_{2}$ emissions of various materials from European countries, where the emission factor of aluminum was $8.24 \mathrm{~kg} \mathrm{CO} 2 \mathrm{e} / \mathrm{kg}$ and that of cast aluminum was $11.70 \mathrm{~kg} \mathrm{CO}_{2 \mathrm{e}} / \mathrm{kg}$. A similar study by Ruuska [29] determined the emission factor 
in aluminum to be $2.264 \mathrm{~kg} \mathrm{CO} 2 \mathrm{e} / \mathrm{kg}$. The world average was presented by Gautam et al. [32] at $23.96 \mathrm{~kg} \mathrm{CO}_{2 \mathrm{e}} / \mathrm{kg}$. Considering the IOA factor in Ref.[25], approximately assessed with the cost, the factor was $6.097 \mathrm{~kg} \mathrm{CO}_{2} / \mathrm{kg}$ for the nonferrous metal sector. The arithmetic average was $13.042 \mathrm{~kg} \mathrm{CO} / \mathrm{kg}$, which is close to the value obtained by the study of Zhang et al [31].

Because of such large variations in embodied GHG of aluminum, which contributes significantly to the CFP of the studied product, this study provided a variation of the mold CFP from different data sources specified above.

\section{Embodied Emissions in Capital Inputs}

Capital inputs, including machine, capital materials, and components flow (from the vertical flow in Figure 1) were also allocated to each type of mold based on its production characteristics.

Table 6. CFP in Capital Inputs

\begin{tabular}{lccc}
\hline \multicolumn{1}{c}{ Machines } & Cost Share & Sector Mold & Element Mold \\
\hline Laser cutting machine & $20 \%$ & 20.720 & 34.848 \\
Master milling machine & $6 \%$ & 6.216 & 10.454 \\
Silicone mixing machine & $1 \%$ & 1.129 & 1.899 \\
Plaster mixing machine & $30 \%$ & 30.045 & 50.529 \\
Low pressure casting machine & $15 \%$ & 15.540 & 26.136 \\
Aluminum milling machine & $28 \%$ & 29.009 & 48.787 \\
\hline \multicolumn{1}{c}{ Total } & & $\mathbf{1 0 2 . 6 5 9}$ & $\mathbf{1 7 2 . 6 5 4}$ \\
\hline
\end{tabular}

For considering the capital inputs, process machines, including the milling, laser cutting, mixing, and casting machines were assumed to be obtained from the local machinery sector. The share of embodied GHG emissions with respect to each machine in the sector and element molds have been assessed and presented in Table 6. Their CFP allocations were assessed based on the assumption that machines were used to produce any type of mold throughout their 20year lifetime. This assumption was based on the unit of equivalent mold tourisme* standard (EMTS), a unit equivalent to different tread molds produced by an individual process machine, because each machine could produce various tread mold models (*Tourisme is a technical term in the mold industry that represents a passenger car). EMTS was used for weighing the contribution process time of each machine for either the sector type or the element type. Furthermore, the production capacity achieved by utilizing each machine in the production of each segment of the sector tread mold is higher than that achieved by utilizing each machine in that of the element tread mold; however, the required inputs inside the set of molds was low. Using Equation (3), the share of capital cost was evaluated along with the CFP of machines produced by the Thai wood and metal working machines sector, which amounted to a factor of 35.27 ton $\mathrm{CO}_{2 \mathrm{e}}$ /million baht [25]. The decommissioning data was not considered while performing this assessment.

\section{Results and Discussion}

The embodied GHG emissions generated by the tire tread mold, obtained using embodied GHG emissions by aluminum from Thai IO-based data [25], are shown in Figure 3. They amount to $5,033.36 \mathrm{~kg} \mathrm{CO}$ e for the sector type and 7,737.77 $\mathrm{kg} \mathrm{CO}_{2 \mathrm{e}}$ for the element type. The highest contributor was the electricity consumption of the process machines $(54.00 \%$ 
for sector type and $43.48 \%$ for element type), followed by embodied emissions of stainless steel (29.71\% for sector type and $19.33 \%$ for element type) and aluminum ingot (6.70\% for sector type and $22.33 \%$ for element type).

The production processes of these two tread molds resemble each other, but differ in their individual time and resources consumptions. Because of the need of a larger segment to be assembled in a set of tread molds, the sector mold process requires lower batches of aluminum casting, which indicates less need of related materials, energy, and GHG emissions in its upstream process.

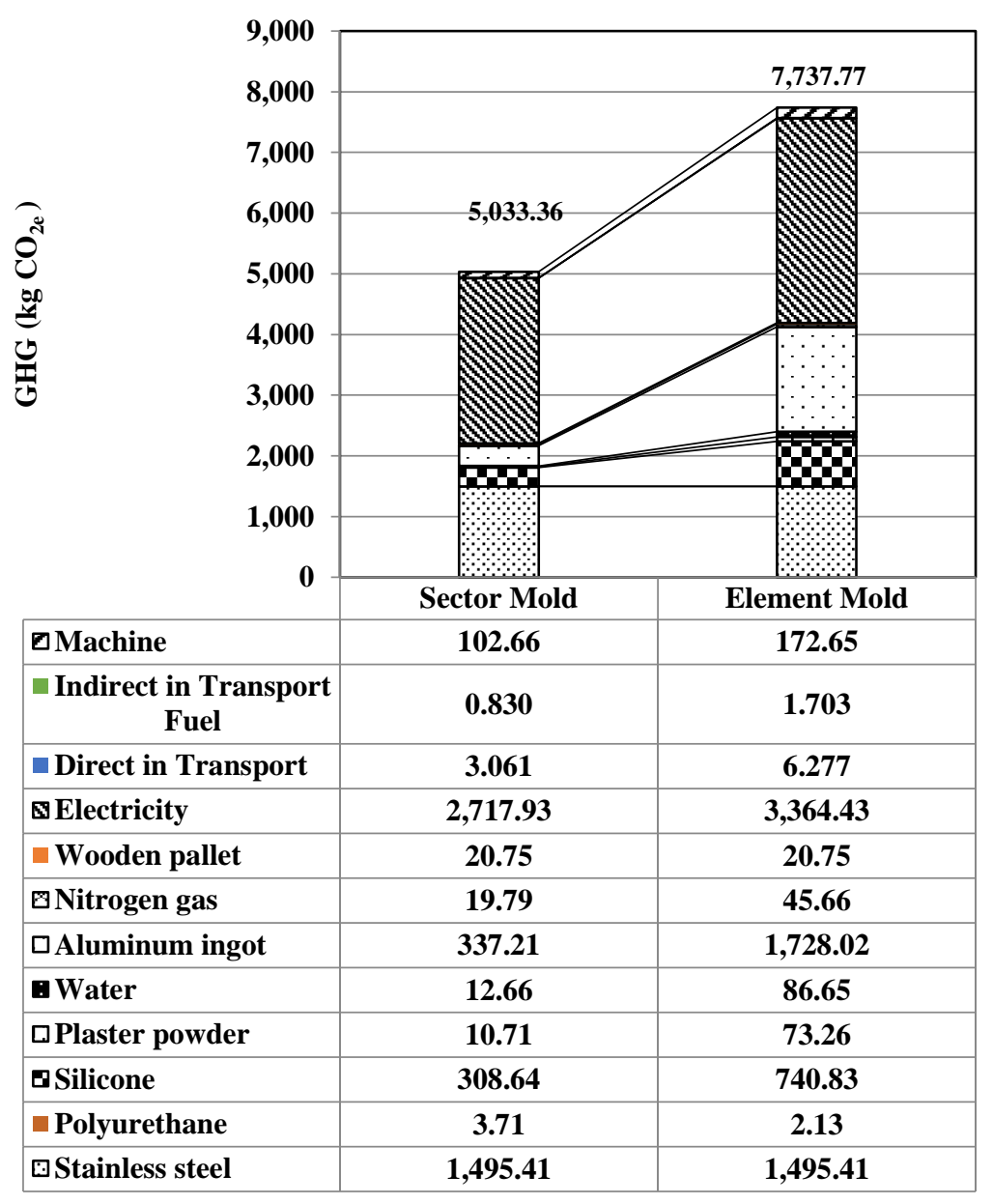

Figure 3. Embodied GHG emissions in tire tread mold

Different raw material requirements between the sector and the element type also affect the reductions in time and the energy consumption by machines. Silicone, gypsum powder, water, aluminum ingot, nitrogen gas, and electricity required by the sector molds are lower than those required by the element molds. The energy consumption of the element mold production machines was higher in processes of gypsum plaster mixing, aluminum low pressure casting, and aluminum milling. Consequently, the energy consumption and embodied GHG emissions were higher in the element mold. This is because the higher output from the plaster casting and aluminum casting process takes more time per set of mold. In contrast, the electricity energy and GHG emissions in the master model milling and silicone mixing processes were lower. This was a 
consequence of the lower amounts of polyurethane required in the master model milling process and the silicone required in the silicone casting process. As a result, the total embodied GHG emissions of the electricity consumption by the sector and the element mold were 2,717.93 $\mathrm{kg} \mathrm{CO}_{2 \mathrm{e}}$ and 3,364.43 $\mathrm{kg} \mathrm{CO}$ e, respectively.

Since each mold requires the same amount of stainless steel and wooden pallet, both the sector and the element molds' embodied emissions are the same at $1,495.41 \mathrm{~kg} \mathrm{CO}_{2 \mathrm{e}}$ and $20.75 \mathrm{~kg}$ $\mathrm{CO}_{2 \mathrm{e}}$ per mold, respectively. The polyurethane required for the master model milling process of the sector mold amounts to $3.71 \mathrm{~kg} \mathrm{CO}_{2 \mathrm{e}}$, which is higher than the element mold $\left(2.13 \mathrm{~kg} \mathrm{CO}_{2 \mathrm{e}}\right)$.

Different raw materials requirements exhibited a 51.26\% reduction of direct $\mathrm{CO}_{2}$ emissions for the transportation of the sector mold's raw materials compared to the element mold. Direct $\mathrm{CO}_{2}$ emissions by diesel fuel in transport amounted to $3.061 \mathrm{~kg}$ and $6.277 \mathrm{~kg}$, while indirect $\mathrm{CO}_{2} \mathrm{emissions}$ were $0.830 \mathrm{~kg}$ and $1.703 \mathrm{~kg}$ for the sector and the element mold, respectively.

Since this result was assessed using embodied GHG emissions for aluminum from the ThaiIOA database $\left(74.74 \mathrm{~kg} \mathrm{CO}_{2 \mathrm{e}} /\right.$ million baht), its variation could significantly influence the tread mold CFP. The results of aluminum CFP variations in the tread mold CFP are presented in Table 7. The sector mold CFP ranged between $4,821.36 \mathrm{~kg} \mathrm{CO}_{2 \mathrm{e}}$ to $6,021.25 \mathrm{~kg} \mathrm{CO}_{2 \mathrm{e}}$. The element mold CFP ranged between $6,651.38 \mathrm{~kg} \mathrm{CO}_{2 \mathrm{e}}$ to $12,800.20 \mathrm{~kg} \mathrm{CO}_{2 \mathrm{e}}$. The mold's CFP using the world average aluminum CFP of Gautam et al. [32] represents the highest value in this study.

Table 7. Variations of Tread Mold CFP by Different Aluminum CFP

\begin{tabular}{|c|c|c|c|c|c|c|c|}
\hline \multirow{2}{*}{$\begin{array}{l}\text { Used Aluminum CFP } \\
\text { from }\end{array}$} & \multirow{2}{*}{$\begin{array}{c}\text { Aluminum } \\
\text { Emission } \\
\text { Factor } \\
(\mathrm{kg} \mathrm{CO} 2 \mathrm{~kg})\end{array}$} & \multicolumn{2}{|c|}{ One Mold CFP } & \multicolumn{2}{|c|}{ One Tire CFP } & \multicolumn{2}{|c|}{$\begin{array}{l}\text { One Set of Tire } \\
\text { CFP in Vehicle }\end{array}$} \\
\hline & & $\begin{array}{l}\text { Sector } \\
\text { mold }\end{array}$ & $\begin{array}{l}\text { Element } \\
\text { mold }\end{array}$ & $\begin{array}{l}\text { Sector } \\
\text { mold }\end{array}$ & $\begin{array}{l}\text { Element } \\
\text { mold }\end{array}$ & $\begin{array}{l}\text { Sector } \\
\text { mold }\end{array}$ & $\begin{array}{l}\text { Element } \\
\text { mold }\end{array}$ \\
\hline $\begin{array}{l}\text { Suksuntornsiri et al. } \\
{[25]}\end{array}$ & 6.097 & $5,033.36$ & $7,737.77$ & 0.168 & 0.258 & 0.671 & 1.032 \\
\hline Ruuska [29] & 2.264 & $4,821.36$ & $6,651.38$ & 0.161 & 0.222 & 0.643 & 0.887 \\
\hline $\begin{array}{l}\text { Hammon and Jonnes } \\
\text { [28] }\end{array}$ & 8.24 & $5,151.86$ & $8,345.03$ & 0.172 & 0.278 & 0.687 & 1.113 \\
\hline $\begin{array}{l}\text { Zhang et. al. [31], } \\
\text { Mining }\end{array}$ & 10.990 & $5,303.95$ & $9,124.40$ & 0.177 & 0.304 & 0.707 & 1.217 \\
\hline $\begin{array}{l}\text { Hammon and Jonnes } \\
\text { [28], cast aluminum }\end{array}$ & 11.70 & $5,343.21$ & $9,325.62$ & 0.178 & 0.311 & 0.712 & 1.243 \\
\hline Zhang et. al.[31], Ore & 13.190 & $5,425.62$ & $9,747.90$ & 0.181 & 0.325 & 0.723 & 1.300 \\
\hline $\begin{array}{l}\text { Das and Kandpal [30], } \\
\text { efficiency Improve }\end{array}$ & 19.570 & $5,778.46$ & $11,556.04$ & 0.193 & 0.385 & 0.770 & 1.541 \\
\hline Das and Kandpal [30] & 21.370 & $5,878.01$ & $12,066.17$ & 0.196 & 0.402 & 0.784 & 1.609 \\
\hline Gautam et al. [32] & 23.96 & $6,021.25$ & $12,800.20$ & 0.201 & 0.427 & 0.803 & 1.707 \\
\hline Average & & $5,491.97$ & $10,087.89$ & 0.183 & 0.336 & 0.732 & 1.345 \\
\hline
\end{tabular}

With an assumption of 30,000 tires produced within a mold's lifetime, the embodied GHG emissions of the sector mold for one tire amount to $168 \mathrm{~g}$, and could range between $161 \mathrm{~g}$ to $201 \mathrm{~g}$. Embodied GHG emissions of the element mold for one tire amount to $258 \mathrm{~g}$ and could range between $222 \mathrm{~g}$ to $427 \mathrm{~g}$. For the sector mold, using different sources for aluminum's embodied emissions in the CFP assessment has a smaller effect on its CFP than for the element mold. The possible variations of 
the tread mold CFP around its average value are larger in the element type. An attempt to apply the tread mold CFP to a tire CFP is also shown Table 7 to estimate the significance of it being overlooked in the tire's CFP. A conventional tire's CFP was quantified by the variable input CFP of a conventional tire, as found in Reference [21].

\section{Conclusions}

The embodied GHG emissions for a set of element type tire tread molds was found to be 7,737.77 $\mathrm{kg}$ $\mathrm{CO}_{2 \mathrm{e}}$, while for a set of sector type tire tread molds, it was only 5,033.36 $\mathrm{kg} \mathrm{CO}_{2 \mathrm{e}}$. Most of the $\mathrm{GHG}$ contribution can be attributed to the production of aluminum, electricity, and stainless steel.

Under the assumption that the sector mold can be substituted with the element mold as a part of the capital input in the tire production process, selecting the sector type could reduce $53.37 \%$ of embodied GHG emissions in the tread mold. The major contribution to GHG emission reduction came from a reduction in the aluminum input, followed by an electricity consumption of the process machine. Lower quantities of silicone, gypsum plaster, and less transportation of raw materials also contributed to the tread mold's CFP reduction.

Although the embodied GHG emissions in a set of tread mold are high in its production industry, they are utilized as the capital input for the tire manufacturing industry. Based on the assumption of 30,000 tires produced within the lifetime of a mold, the embodied GHG emissions of the tire mold for one tire were $168 \mathrm{~g}$ for the sector type and $258 \mathrm{~g}$ for the element type. In the sector mold, using different sources of aluminum's embodied emissions in the CFP assessment have a smaller effect on its CFP in comparison to the element mold. Based on the assumption of adding these embodied emissions into the result of Bras and Cobert [21] (560.4 $\mathrm{kg} \mathrm{CO}_{2 \mathrm{e}}$ ), disregarding the tread mold CFP during the production of a single conventional tire could result in an underestimation of only $0.03 \%$ for the sector type and only $0.05 \%$ for the element type. Reduced lifetime utilization of the tread mold will increase the significance of the mold CFP.

Possible variations of the tread mold CFP can be attributed to the source of different embodied emissions of aluminum on a country-to-country basis. Further, the stage of aluminum product, i.e., ore, ingot, or final product, and its year of production are observed to be affected by its upstream fuel consumption. Relocation of mold production will alter the product's CFP because of the variation in embodied GHG emissions in the CFP of new grid electricity.

A set of tire molds comprises not only the tread mold observed in this study but also the steel mold. Another composition of mold, i.e., a side mold manufactured using steel, should be studied to ensure the total CFP significance of the mold.

\section{References}

[1] J.F. Van de Vate, "Comparison of energy sources in terms of their full energy chain emission factors of greenhouse gases," Energy Policy, Vol. 25, No. 1, pp. 1-6, 1997. doi: 10.1016/S0301-4215(96)00111-5

[2] B. Norton, P.C. Eames, and S.N. Lo, "Full-energy-chain analysis of greenhouse gas emissions for solar thermal electric power," Renewable Energy, Vol. 15, No. 1-4, pp. 131136, 1998. doi: 10.1016/S0960-1481(98)00158-X

[3] M. Lenzen and C. Dey, "Truncation error in embodied energy analyses of basic iron and steel products," Energy, Vol. 25, No. 6, 2000. doi: 10.1016/S0360-5442(99)00088-2 
[4] A.M. Nieslsen, and B.P. Weidema, Input/Output Analysis: Shortcuts to Life Cycle Data?, Environmental Project No. 5812001 [Online]. Available: https://www2.mst.dk/udgiv/Publications/2001/87-7944-365-6/pdf/87-7944-366-4.pdf

[5] M. Lenzen, "A guide for compiling inventories in hybrid life-cycle assessments: Some Australian results," Journal of Cleaner Production, Vol. 10, No. 6, pp. 545-572, 2002. doi: 10.1016/S0959-6526(02)00007-0

[6] P. Suksuntornsiri, and B. Limmeechokchai, "Embedded energy and total greenhouse gas emissions in final consumptions within Thailand," Renewable and Sustainable Energy Reviews, Vol. 11, No. 2, pp. 259-281, 2007. doi: 10.1016/j.rser.2005.01.005

[7] P. Suksuntornsiri, and B. Limmeechokchai, "Total energy content and total greenhouse gas emission factors: the updated Thailand input-output table," Paper presented at The $21^{\text {st }}$ Conference of Mechanical Engineering Network of Thailand, Chonburi, Thailand, p. ETM001, 2007.

[8] W. Loentief, Input-Output Economics, $2^{\text {nd }}$ Edition, Oxford University Press, United States, 1986.

[9] R.E. Miller, and P.C. Blair, Input-Output Analysis: Foundations and Extensions, PrenticeHall, Englewood Cliffs, New Jersey, United States, 1985.

[10] K. Nansai, Y. Morigushi, and S. Tahno, Embodied Energy and Emission Intensity Data for Japan Using Input-Output Tables (3EID)-Inventory Data for LCA, National Institute for Environmental Studies, Japan, 2002 [Online] Available:

http://www.cger.nies.go.jp/publications/report/d031/D031.pdf [Accessed: September 2018]

[11] H. Hondo, S. Sakai, and S. Tanno, "Sensitivity analysis of total $\mathrm{CO}_{2}$ emission intensity estimated using an input-output table," Apply Energy, Vol. 72, No. 3-4, pp. 689-704, 2002. doi: 10.1016/S0306-2619(02)00059-4

[12] K.R. Voorspools, E.A. Brouwers, D'haeseleer, and D.William, "Energy content and indirect greenhouse gas emissions embedded in emission-free power plants: Results for the low countries," Applied Energy, Vol. 67, No. 3, pp. 307-330, 2000.

[13] K. Tadtiemporn, Carbon Footprint of Sticky Rice in Bamboo, Thesis (Master's), Burapha University, Chonburi, Thailand, 2017.

[14] I. Yi, N. Itsubo, A. Inaba, and K. Matsumoto, "Development of the interregional I/O based LCA method considering region-specifics of indirect effects in regional evaluation," The International Journal of Life Cycle Assessment, Vol. 12, No. 6, pp. 353-364, 2007. doi: 10.1065/lca2007.06.339

[15] G. Cicas, C.T. Hendrickson, A. Horvath, and H.S. Matthews, "A regional version of a US economic input-output life-cycle assessment model," International Journal of Life Cycle Assessment, Vol. 12, No. 6, pp. 1-8, 2007. doi: 10.1065/lca2007.04.318

[16] C.W. Bullard III, and R.A. Herendeen, "The energy cost of goods and services," Energy Policy, Vol. 3, No. 4, No. 268-278, 1975. doi:10.1016/0301-4215(75)90035-X

[17] P.F. Chapman, "Energy costs: A review of methods," Energy Policy, Vol. 2, No. 2, 1974. doi:10.1016/0301-4215(74)90002-0

[18] International Atomic Energy Agency (IAEA), Comparison of Energy Sources in Terms of Their Full-energy-chain Emission Factors of Greenhouse Gases (Proceedings of an IAEA Advisory Group Meeting /Workshop), IAEA-TECDOC-892, IAEA, Beijing, China, 1996.

[19] International Organization of Motor Vehicle Manufacturers (OICA), Data from: 2017

Production statistics, [dataset], OICA [Online]. Available:

http://oica.net/category/production-statistics [Accessed: January 2019] 
[20] C.H. Chu, M.C. Song, and V.C.S. Luo, "Computer aided parametric design for 3D tire mold production," Computers in Industry, Vol. 57, No. 1, pp. 11-25, 2006.

[21] B. Bras, and A. Cobert, "Life-cycle environmental impact of Michelin Tweel® Ttire for passenger vehicles," SAE International Journal of Passenger Cars - Mechanical Systems, Vol. 4, No. 1, pp. 32-43, 2011, doi: 10.4271/2011-01-0093

[22] International Organization for Standardization, Greenhouse Gases-Carbon Footprint of Products Requirements and Guidelines for Quantification (ISO/TS 14067:2018), Géneve, Switzerland, 2018.

[23] International Organization for Standardization, Environment Management - Life Cycle Assessment - Requirement and Guidelines (ISO14044:2006/Amd.1:2017(en)), Géneve, Switzerland, 2006.

[24] Intergovernmental Panel on Climate Change (IPCC), 2006 IPCC Guidelines for National Greenhouse Gas Inventories, Institute for Global Environmental Strategies (IGES), Japan, 2006 [Online]. Available: https://www.ipcc-nggip.iges.or.jp/public/2006gl/ [Accessed: July 2018]

[25] P. Suksuntornsiri, P. Limpitipanich, W. Tia, and and B. Limmeechokchai, "Embodied primary energy and $\mathrm{CO}_{2}$ emission intensity in Thai commodities based on PDP2010: An input-output analysis," In: The $6^{\text {th }}$ AUN/SEED-Net Regional Conference on Energy Engineering (RCEneE), p. D004, 2013.

[26] Department of Altenative Energy Development and Efficiency, 2017 Electric Power in Thailand 2017 [Online]. Available:

http://www.dede.g.,o.th/download/state_61/Energy\%20Balance\%20of\%20Thailand\%2020 17.pdf [Accessed: August 2018]

[27] National Economic and Social Development Board (NESDB), Data from: 2010 inputoutput table [data set], NESDB [Online]. Available: http://www.nesdb.go.th [Accessed: January 2019]

[28] G.P. Hammon, and C.I. Jonnes, "Embodied energy and carbon in construction materials," In: Proceedings of the Institution of Civil Engineers-Energy, University of Bath, United Kingdom, 2008, doi: 10.1680/ener.2008.161.2.87

[29] A. Ruuska, Carbon Footprint for Building Products-ECO2 Data for Materials and

Products with the Focus on Wooden Building Products [Online]. Available: https://www.vtt.fi/inf/pdf/technology/2013/T115.pdf [Accessed: January 2019]

[30] A. Das, and T.C. Kandpal, " $\mathrm{CO}_{2}$ emissions from aluminum manufacturing in India," Energy, Vol. 23, No. 2, pp. 145-152, 1998. doi: 10.1016/S0360-5442(97)00071-6

[31] W. Zhang, H. Li, B. Chen, Q. Li, X. Hou and H. Zhang, " $\mathrm{CO}_{2}$ emission and mitigation potential estimations of China's primary aluminum industry," Journal of Cleaner Production, Vol. 103, pp. 863-872, 2015. doi: 10.1016/j.jclepro.2014.07.066

[32] M. Gautam, B. Pandey, and M. Agrawal, "Carbon footprint of aluminum production: Emissions and mitigation," In Environmental Carbon Footprints: Industrial Case Studies, Butterworth-Heinemann, United Kingdom, pp. 197-228, 2018. 